\title{
Preparing to Work with Generation $\mathbf{Z}^{1}$
}

\author{
Cecilia E. Suarez and Valerie McKee ${ }^{2}$
}

\section{The Problem}

As agriculture becomes more dependent on and enhanced by technology, team members possessing in-depth technical skills will be extremely valuable to the success of the industry. However, members of Generation Z, the technologically savvy, incoming generation of college graduates and future members of the workforce, will require specific leadership and support to reach their potential and contribute to the needs of the agriculture industry.

\section{Purpose}

We write this particular publication with two purposes in mind. First, we intend to describe Generation Z. Second, we offer the best-known practices for preparing this generation to uniquely contribute to the solutions needed in Florida's agriculture and natural resource industries.

\section{Generational Theory}

As both the population and lifespan of people on Earth grows, so does the recognition of distinct generations, each with their own distinctive characteristics. Howe and Strauss (2000) claim that generations are defined by three different factors: perceived membership, or the self-perception of membership within a generation beginning in adolescence; common beliefs and behaviors, such as the shared values and attitudes of a generation that help to define generational boundaries; and a common location, which includes the turning points found in historical events and trends that occur during a generation's formative years (Reeves \& Oh,
2008). In today's world, we recognize five different generations in the workplace. Howe and Strauss (2000) have contributed to what we understand about these generations and their distinctive characteristics through the assertion that shared experiences in history, even more so than shared birth years, is what truly defines a generation.

Members of the Silent Generation, born between 1925 and 1943 (Howe \& Strauss, 2000), exemplify workplace values such as integrity, responsibility, loyalty, and honor for authority as a result of their shared experiences after the Great Depression and World War II. Members of the Baby Boomer Generation, born between 1944 and 1960 (Howe \& Strauss, 2000), display workplace traits such as a strong work ethic, being team-centered, and carrying idealistic goals and views as a result of experiencing controversial events such as the Korean War, Woodstock, and the assassinations of President John F. Kennedy and Martin Luther King. Members of Generation X, born between 1961 and 1981 (Howe \& Strauss, 2000), share workplace characteristics such as a preference for working independently, a healthy fear and criticism of the unknown, and an entrepreneurial spirit because of experiences like the Challenger explosion, the rise of the personal computer, and the fall of the Berlin Wall. Millennials, born between 1982 and 1995 (Oblinger, Oblinger, \& Lippincott, 2005), are known for their drive for personal achievement, their positive, changethe-world outlook, and their global worldview as a result of their shared experiences of extracurriculars and pressure to attend college, their memories of September 11, the rise of the internet, and the expansion of social media. Members

1. This document is AEC648, one of a series of the Agricultural Education and Communication Department, UF/IFAS Extension. Original publication date August 2018. Visit the EDIS website at http://edis.ifas.ufl.edu.

2. Cecilia E. Suarez, assistant professor; and Valerie McKee, doctoral student; UF/IFAS Extension, Department of Agricultural Education and Communication, Gainesville, FL 32611.

The Institute of Food and Agricultural Sciences (IFAS) is an Equal Opportunity Institution authorized to provide research, educational information and other services only to individuals and institutions that function with non-discrimination with respect to race, creed, color, religion, age, disability, sex, sexual orientation, marital status, national origin, political opinions or affiliations. For more information on obtaining other UF/IFAS Extension publications, contact your county's UF/IFAS Extension office. 
of Generation Z, born between 1995 and present (Seemiller and Grace, 2016), have their own distinct traits formed from their own unique experiences.

\section{Generation Z in a Nutshell}

In a major study that encompassed more than 1,000 Generation Z participants, Seemiller and Grace (2016) identified several characteristics unique to this generation. First, they proposed that this generation is the most ethnically diverse generation ever known. Generation $\mathrm{Z}$ represents 25 percent of the US population and is projected to become a third of the population by the year 2020 (Seemiller \& Grace, 2016). The oldest Generation $\mathrm{Z}$ members experienced the events of September 11, the 2008 recession, and the consequential increase in unemployment. Just like their Generation $\mathrm{X}$ parents, this generation is expected to be both independent in spirit and entrepreneurial in their work style, as they already appear to have self-directed learning styles in the classroom.

With unlimited videos, pictures, and miscellaneous information at their fingertips, this generation has known the effects of global and historical events more personally compared to their predecessors, and has known these effects earlier in their formative years. Generation Z's view of the world has been largely shaped by the broad use of the Internet, and their inseparable connection to technology has both assisted and hindered their abilities as a communal citizen. Their constant use of technology has allowed for continuous connection with peers, allowing them to form a sense of empathy and compassion. Seemiller \& Grace (2016) predict that Generation Z's experiences will result in their development of compassion, loyalty, thoughtfulness, open-mindedness, and responsibility. However, Elmore (2010) argues that while technology is seen as completely vital to this generation's well-being, it has lowered their motivation to be involved in activism and advocacy, and has made them more ambiguous about their future.

For his book Generation iY: Our Last Chance to Save their Future, Elmore (2010) interviewed thousands of Generation $\mathrm{Z}$ students to understand their differences when compared to older millennials. Elmore (2010) determined 26 phrases that will most likely be heard from this generation. Some phrases identified by Elmore (2010) include:

1. "I'm overwhelmed, but I'm dealing with it."

2. "I’m impatient. I make short-term commitments."

3. "I’m living in a greener world."
4. “I'm living in a virtual world. (I plan to try a virtual marriage.)"

5. "I've learned to do things faster. My pace of life is accelerated."

While these statements are not always specific to Generation $\mathrm{Z}$, it is important to understand the impact and common theme that these statements convey about the way Generation $\mathrm{Z}$ often experiences society and the world at large. Generation $Z$ has grown up in a society that relies on technology and instant problem-solving solutions. They are quick at finding solutions and troubleshooting and are used to multitasking to complete tasks quickly. As such, some tasks that one might anticipate taking a day or so might take a few hours for some Generation $\mathrm{Z}$ employees.

\section{Best Practices for Preparing Generation Z}

The longevity of an operation and business will depend in part on the youngest employees. As baby boomers retire, generations $\mathrm{X}, \mathrm{Y}$, and $\mathrm{Z}$ are entering the workforce. Each group approaches life and career differently, and industry professionals and agriculture educators can benefit from understanding how to work with Gen Z. Below are some tips for successfully engaging Generation Z-ers in the workplace:

\section{Provide clear direction. Generation $\mathrm{Z}$ prefers more} structure and direction. They will look to managers to provide clear guidance and ongoing feedback. While grappling with ambiguity may be constructive during various points of identity and leadership development, clear direction and instruction in the workplace and for project completion is imperative for ensuring quality of task completion, clear communication establishment, and overall success of a positive working relationship.

\section{Praise, rewards, and feedback go a long way. Generation} $\mathrm{Z}$ doesn't want to be left wondering whether or not they have done a good job. They expect their managers and bosses to tell them directly.

3. Flexibility is key. Generation $\mathrm{Z}$ knows how to manage life on the go. They have no problem with being able to focus and get work done from anywhere. This flexibility extends further than simply where they can get work done. It extends into a blurring of the lines between personal and work time, which Generation $\mathrm{Z}$ workers are able to achieve and manage quite seamlessly. 
4. Embrace technology. Generation $\mathrm{Z}$ has never lived without technology. It's part of their personal lives and they expect the same in their work lives. Utilizing technology for employee memos, trainings, and providing opportunities for this generation of workers to use technology within their roles will keep them excited and connected.

\section{An Important Warning to Educators, Mentors, and Supervisors}

As previously stated, Generation $\mathrm{Z}$ is the most ethnically and racially diverse generation in history (Seemiller \& Grace, 2016). Not only will this group be culturally diverse, but their values, family dynamics, political perspectives, and overall life experiences vary greatly. As such, a onesize-fits-all approach to working with this population is harmful to their overall success in the workplace. While best practices for working with this generation are offered in this publication, it is important to note that every person holds a number of unique identities that makes the application of best practices one part of the overall way Generation Z-ers need to be supported. Generalizations may be helpful initially when preparing and building for new Generation $\mathrm{Z}$ employees, but employers must build upon these generalities by getting to know each person as an individual and inquiring about how they best function. Utilizing the best practices provided in this paper will assist in better understanding Generation $\mathrm{Z}$ employees and team members, but remember that the old rule still holds true if ever uncertain about how to best engage a new Generation $\mathrm{Z}$ employee: when in doubt, ask.

\section{References}

Elmore, T. (2010). Generation iY: Our last chance to save their future. Atlanta, GA: Growing Leaders, Inc.

Geck, C. (2007). The generation $\mathrm{Z}$ connection: Teaching information literacy to the newest net generation. Toward a 21st-Century School Library Media Program, 235.

Howe, N. and Strauss, W. (2000). Millennials Rising: The Next Great Generation. New York: Vintage Books.

Oblinger, D., Oblinger, J. L., \& Lippincott, J. K. (2005). Educating the net generation. Boulder, Colo.

Reeves, T. C., \& Oh, E. (2008). Generational differences. Handbook of research on educational communications and technology, 3, 295-303.
Seemiller, C., \& Grace, M. (2016). Generation Z goes to college. San Francisco, CA: Jossey-Bass. 